\title{
The Role of Intergenerational Transmission of Parenting in Close Relationships of Male and Female Adolescents
}

Mira Klarin

Associate professor, Department of Teachers' and Preschool Teachers' Education, University of Zadar

Ana Proroković

Full professor, Department of Psychology, University of Zadar

\section{Ana Šimunić}

Assistent, Department of Psychology, University of Zadar

Doi:10.5901/mjss.2014.v5n20p1821

\section{Abstract}

The purpose of this study was to explore intergenerational continuity of parenting through three generations and its influence on the social relationships of male and female adolescents. 898 adolescents (378 male and 520 female) from Croatia, Bosnia and Macedonia, with an average age of 16.5, participated in this research. The following measuring instruments (self-report measures) were used: the relationship of mother/father with grandparents, the Perception of Family Interactions Scale, the Friendship Quality Scale, and the Social Loneliness Scale. The results of this study confirm the hypothesis of the intergenerational transmission of parenting. Moreover, they show that the mother's parental style has a stronger effect on friendship quality in female adolescents than the father's parental style. Generally, it should be noted that the results of this research show that the mother's parental style has a greater impact on friendship quality and social loneliness for girls than for boys.

Keywords: intergenerational transmission, adolescents, parenting, friendship quality, social loneliness

\section{Introduction}

The role of parents in a child's development is extremely important; therefore, interest in studying parenting and its impact on developmental outcomes dates far back into history. Given the complexity and dynamics of parenting, studies have varied greatly, from studying parenting styles, partnerships and divorces, to studying parenting through the life span, the ecology of parenting, making cross-cultural comparisons, etc. Results of many studies point out the formative role of parents in child development and suggest that parenting is very important for understanding children's mental health (Campbell \& Gilmore, 2007; Castellana, Vilar, \& Rodriguez-Tome, 1997; Choo, 2000; Colin, 1996; Klarin, Šimić Šašić, \& Proroković, 2012).

The belief that parents play an important role in children's social development is well ensconced in the field of developmental psychology, and it is well documented through a variety of research employing various outcome variables (Maccoby, 2008; Bowlby, 1973; Buist, Deković, Meeus, \& van Aken, 2004; Deković \& Buist, 2005; Eichelsheim, Deković, \& Buist, 2009; Sharma \& Vaid, 2005). They could also play a significant role when it comes to the type of parents their own children will be in the future (Feldman \& Goldsmith, 1986; Van ljzendoorn, 1992). Intergenerational transmission of parenting can be defined as the transmission of parenting styles from generation to generation. Although research on intergenerational continuity (or transmission) is relatively rare, most of these studies have documented the intergenerational transmission of parenting and indicate that present-day parents tend to practice parenting styles which are similar to those they received in their own childhood (Putallaz, Costanzo, Grimes, \& Sherman, 1998; Chen \& Kaplan, 2001). Research results increasingly support the importance of the intergenerational transmission of negative parental practices, which are associated with risky behaviour in children (Campbell \& Gilmore, 2007; Shaffer, Burt, Obradović, Herbers, \& Masten, 2009) and with low academic achievement (Serbin et al., 1998; Serbin \& Karp, 2004; Goodnow, 1995). Research results support the hypothesis of abuse transmission, i.e., the tendency of those who were abused by their parents to abuse their own children as well (Serbin \& Karp, 2004; Pears \& Capaldi, 2001; Fry, 1993). There is also a 
tendency of divorce transfer, shown in the more frequent divorces among partners from divorced families (Amato, 1996; Dronkers \& Härkönen, 2008; Amato \& Cheadle, 2005; Kunz, 2000).

Intergenerational transmission of parenting is studied most frequently by collecting data on three generations: grandparents, parents, and children (Bailey, Hill, Oesterle, \& Hawkins, 2009; Roskam, 2013). Since intergenerational transmission involves the transfer of behaviour, beliefs, attitudes and values, it is part of a socialization process where older generations transmit patterns of behaviour and beliefs to younger generations, which further transmit these patterns to their own children. Current theory, supported by a growing body of empirical research, strongly suggests a combination of genetic and environmental influences in producing intergenerational similarities between parents and children (Serbin \& Karp, 2003; 2004). It is very difficult to distinguish the effects of genes and shared environment from the effects of intergenerational transfer. However, the influence of genes from one generation to another determines one's disposition or tendency of response in a particular social environment, which includes parenting (Van ljzendoorn, 1992). A direct model of parenting has been proposed by Van ljzendoorn (1992), which would look like the model displayed in Figure 1. This model excludes the impact of grandparents on grandchildren, since it is not a subject of research on intergenerational transmission of parenting (G1 - grandparents, G2 - parents, G3 - children). General support has been found for the idea that direct modelling of parental behaviour leads to the transfer of that behaviour from one generation to the next (Van ljzendoorn, 1992).

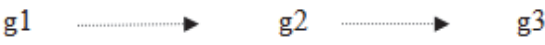

Figure 1. A direct model of intergenerational transmission of parenting (according to Van ljzendoorn, 1992)

Learning is one of the possible mechanisms in explaining the intergenerational transmission of parenting. It is possible to highlight three learning mechanisms (Crittenden, 1984): observational learning, which includes watching parents interact with another child, a child's previous experience in interacting with parents, and parental coaching. According to the Social Learning Theory, people have the ability to retain early images in their memory for later modelling and behaviour. The social learning process was highlighted in research on the intergenerational transmission of abusive or harsh parenting, a process which also takes a significant place in the intergenerational transmission of constructive parenting (Chen \& Kaplan, 2001). Chen and Kaplan (2001) found that social learning is a primary mechanism of the intergenerational transmission of constructive parenting. They assumed that there is a direct effect of the early experience of supportive parenting on later parenting strategies.

Another mechanism that could explain the intergenerational transmission of parenting is the mechanism of attachment (Bowlby, 1973). Bowlby assumed that a child forms an internal working model, which refers to the self and to others, during early mother-child interactions. This internal working model makes a prototype for later social relationships and is relatively stable throughout life (Collins \& Read, 1994). The Attachment Theory also assumed that adults' relationships are associated with the relationship between them and their own parents through the experience of responsiveness, rejection or ambivalence during their childhood (Crittenden, 2008). Such experience is responsible for the formation of an internal working model or internal representations which later determine the level of compassion in the relationship between them and their own children.

An interesting issue which follows the previous section is the issue of gender effects on the intergenerational transmission of parenting and on social development. Many authors (Simon, Whitbeck, Conger, \& Chyi-In, 1991; Rutter, Quinton, \& Hill, 1990; Herman, 1995; Tanaka, Katamura, Chen, Murakami, \& Goto, 2009) emphasize the specificity of parental style and of its transmission according to parent gender. For example, Tanaka et al. (2009) point out that protection as a parenting style is transferred from the grandfather to the father, while nurturing is transferred from the grandmother to the mother.

The results of a meta-analysis conducted by Van ljzendoorn (1995) revealed a stronger correspondence between the attachment representations of mothers and their children than between those of fathers and their children. Many of the studies in this meta-analysis involved measurements based on the Strange Situation Procedure (developed by Mary Ainsworth in the 1970s), which may be inappropriate, since it was developed and validated to measure the mother-child relationship. Moreover, the difference between the mother's and father's parental influence is explained by the parentalinvestment theory. According to this theory, the mother and father invest in the child in different ways: the mother is involved in parenting, the father in mating. Mothers spend significantly more time interacting with their children than fathers do in all cultures (Bjorklund \& Shackelford, 1999; Geary, 2005; Buss, 2005). Gender differences in parental investment relate to females reflecting high parental investment and resultant long-term mating strategies, and males demonstrating low parental investment and resultant short-term mating strategies (Geher et al., 2007). One frequent 
explanation for the weaker influence of fathers and a weaker father-child attachment relates to the role of fathers in Western industrialized countries: fathers typically have fewer caretaking tasks, fewer responsibilities, and less intensive involvement than mothers (Putallaz et al., 1998). Earlier studies suggest that fathers and mothers have different types of relationships with their daughters and sons (Youniss \& Smollar, 1985). In general, the role of the mother is mostly protective and caring, and the role of the father is instrumental (Deković \& Raboteg-Saric, 1997). The role of the mother is also more inclusive, as opposed to the role of the father. The mother is more involved in her children's lives than the father is (Bukatko \& Daehler, 2001; Colin, 1996). Furthermore, these interactions may be specific in relation to a male or a female child. Research results show that fathers use an authoritarian parenting style towards daughters in order to control and influence them (Youniss \& Smollar, 1985; Deković \& Raboteg-Saric, 1997). Boys also often describe their relationship with their father as authoritarian, but they talk with their father about some common interests more often than girls do (Youniss \& Smollar, 1985). Men form less intimate friendships, and they describe a friendly relationship in terms of time spent in activities together (Buhrmester, 1996). In mutual interactions, girls often talk about emotions and share confidential contents (Way, 2006). For this reason, the mother has more opportunities to influence her daughter's attitudes towards friends (Updegraff, McHale, Grouter, \& Kupanoff, 2001). A friendship that involves sharing, entrusting and intimacy is important to girls, while socializing and spending time in a joint activity is important to boys (Way, 2006; Buhrmester, 1996). When speaking of harsh parenting, authors Simon et al. (1991) suggested an association between the father's harsh parenting towards sons with the grandmother's harsh parenting towards the father, while harsh parenting towards daughters is associated with harsh parenting of the grandfather towards the father. On the other hand, harsh parenting of the mother towards both her son and daughter is associated with a harsh relationship between the mother and grandmother.

The aim of this study was to explore intergenerational continuity of parenting and its influence on the social relationships of male and female adolescents. The focus was on exploring the role of the father's and mother's parental styles and their relationship with their own parents in the friendship quality and social loneliness of adolescents. We were also interested in the effect of transmission with respect to the parents' and adolescents' gender.

One of the hypotheses of this study was that those who have (or had) a good relationship with their parents have a good relationship with their adolescent children, and vice versa: parents who do (or did) not have a good relationship with their parents do not have a good relationship with their adolescent children. Thus, we tried to determine how individuals' childrearing experiences influence their own parenting through the parental working model formed on the basis of their affective relationships with their parents. We also assume different intergenerational transmission effects according to the adolescents' and parents' gender.

The hypothesized model is shown in Figure 2. It builds on the direct model explained in the introduction, further assuming that the same model could be more complex with more interactive links in the transmission process, especially when it comes to the adolescents' father's and mother's parenting styles.

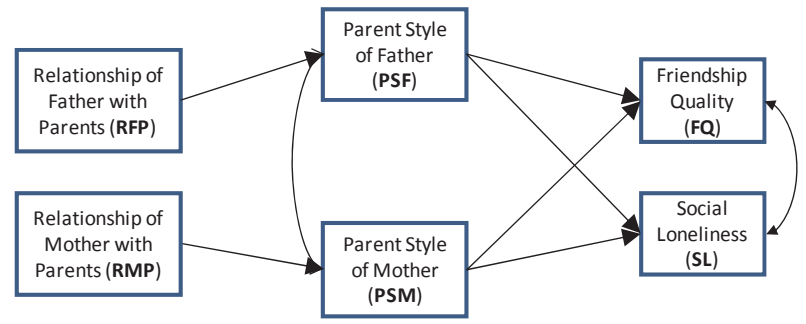

Figure 2. Hypothesized model of intergenerational transmission of parenting and its role in adolescents' close relationships.

\section{Methods}

\subsection{Participants}

898 adolescents from Croatia, Bosnia \& Herzegovina, and Macedonia participated in this research. There was a total of 378 male and 520 female adolescents with an average age of 16.5 (range 14 to 19). The participating adolescents were high-school students from two first-year, two second-year, two third-year, and two fourth-year classes in grammar schools 
and vocational schools in each country. In all three countries, there was an equal number of grammar-school and vocational-school students, as well as an equal number of students from all four years.

\subsection{Procedure}

The research was conducted in three countries: in the Republic of Croatia, and in Bosnia and Herzegovina, during April 2007, and in Macedonia during October of the same year, over a two-week period. The research included two grammar schools and two vocational schools in the above countries. The application of measuring instruments in each group lasted less than one school hour during regular classes. The instruments were applied by the school psychologists.

The relationships of interest were evaluated by the adolescents (self-report measures). Thus, the adolescents (G3) assessed the relationship between their parents (mother and father - G2) and their parents' parents (grandparents - G1) and their own relationship with their parents (the relationship of adolescents G3 with parents G2). In this way, we indirectly included three generations and parenting in two generations. It should be emphasized that this methodology represents an indirect manner of inferring about possible intergenerational transmission, and it thus does not have the strength of a classical longitudinal study. However, we believe that data obtained in this way may nonetheless be valuable in providing guidance for future research and in making a significant contribution to explaining some aspects of the intergenerational transmission of parenting.

We tested these assumptions (hypothesized model in figure 2) by conducting path analysis on the entire sample, which was followed by multigroup path analysis (boys vs. girls) using the Mplus program (version 6).

\subsection{Instruments}

The relationship of mother/father with grandparents was assessed by the adolescents on a 5-degree scale with the following item: "How would you evaluate the relationship between your parents and their parents (your grandparents) or what their relationship was like, if your grandparents have passed away?" The adolescents assessed their mother's relationship with her parents and their father's relationship with his parents (regardless of the grandparents' gender). If they estimated that the relationship was bad, they were to mark 1 on the assessment scale, and if they estimated that the relationship was very good, they were to mark number 5 .

The Perception of Family Interactions Scale (Macuka, 2007) measures the perception of parental (mother's and father's) behaviour in three dimensions: rejection, acceptance and psychological control. The adolescents assessed these parental behaviours on a 5 -degree scale ( 1 - not at all true; 5 - completely true). The Rejection subscale contains eight items such as "Does not show me he/she loves me" and "I feel that he/she does not notice me". It measures a negative emotional relationship between the child and his/her mother and father, which is manifested in a lack of emotional support. Rejection by the mother explained $46.3 \%$ of the common variance of the eight items, while rejection by the father explained 38.1\%. 'Acceptance' refers to a positive emotional relationship between the parent and child, such as "My mother/father and I have an honest relationship" and "My father/mother gives me security". This subscale consists of 7 items. Acceptance by the mother explained $34.6 \%$ of the common variance of the seven items, while acceptance by the father explained $36.3 \%$. The dimension of psychological control relates to behaviour aimed at modifying the child's behaviour, such as punishment, making threats, underestimating, comparison with other children, and similar. This subscale consists of 10 items such as "Makes fun of me in front of others" and "Rarely smiles at me". Psychological control by the mother explained $39.0 \%$ of the common variance of the ten items, while psychological control by the father explained $36.7 \%$. The Cronbach alpha coefficients of internal reliability for the subscales on the whole sample were satisfactory and ranged from 0.74 to 0.82 . For the purpose of this study, the measure of parental behaviour was calculated separately for mothers and fathers. The results of the three dimensions were summed, while respecting direction (lower acceptance, higher rejection, and higher psychological control) ${ }^{1}$. This formed two linearly combined variables: parenting style of the mother and parenting style of the father.

The Friendship Quality Scale (FQ) (Klarin, 2000) consists of 30 items which evaluate the subjects' relationship with their best friend ("Think of your best friend") and the degree of emotional support and conflict resolution, as well as mutual helping and sharing, in their relationship. The subjects' task was to assess the accuracy of each item on a fivepoint scale, where 1 meant that the item was not true at all and 5 meant that it was completely true. The Cronbach alpha reliability coefficient for this scale was 0.94 . The scale showed a one-factor structure and explained $38.77 \%$ of the

\footnotetext{
${ }^{1}$ Generally, empirical research results show that the parental style described is associated with negative social and psychological adjustment in adolescents.
} 
common variance. The result on this scale was interpreted as the level of friendship quality. Some of the items included in this scale were: "We always lend things to each other," "My friend defends me if someone gossips about me," and "We rely on each other."

The Social Loneliness Scale (SL) (Ćubela-Adorić \& Nekić, 2004) consists of 13 items and measures whether individuals find that their friendships ("Think of your closest friends") satisfy their needs for understanding, support and intimacy. Some example items from this scale are: "My friends understand my needs and way of thinking" and "I am not satisfied with the friends I have." Cronbach's alpha reliability coefficient for this scale is satisfactory and was 0.86 , explaining $38 \%$ of the common variance.

Both the Friendship Quality Scale and the Social Loneliness Scale have a one-dimensional structure.

\section{Results}

In the first step of statistical analysis, the data was evaluated for missing data, outliers and non-normality, using the program STATISTICA 11. Neither missing data nor outliers were detected. Normality of the data was examined by marking the skewness and kurtosis of the univariate data. All of the distributions meet the criteria suggested by Kline (2011): that is, the skewness indices were all lower than 3 and the kurtosis indices were all lower than 8.

Other basic descriptive parameters of the examined variables and the correlations between them were calculated using the same program. These parameters were evaluated on the entire sample (with descriptive parameters shown in Table 1 and correlations shown in Table 3) and separately for the gender subsamples (with descriptive parameters shown in Table 2 and correlations in Table 4). Since a linear relationship between the manifest variables is also a prerequisite for the planned analyses (Tabachnick \& Fidell, 2001), linearity between all pairs of variables was checked and determined by visual inspection of the scatterplots. All of the correlations were statistically significant at a $p<.001$ level.

Table 1. Basic descriptive parameters (minimum result, maximum result, mean, and standard deviation) of the variables measured on the entire sample of the present study, along with the abbreviations of the variable names used in all the following tables and figures.

\begin{tabular}{lcccc}
\hline Variable - Abbreviation & $\min$ & $\max$ & Mean & SD \\
\hline Relationship of Father with Parents - RFP & 1 & 5 & 4.17 & 0.894 \\
\hline Relationship of Mother with Parents - RMP & 1 & 5 & 4.45 & 0.780 \\
\hline Parental Style of Mother - PSM & 22 & 100 & 42.99 & 15.04 \\
\hline Parental Style of Father - PSF & 22 & 103 & 45.31 & 15.77 \\
\hline Social Loneliness - SL & 11 & 54 & 20,02 & 7,655 \\
\hline Friendship Quality - FQ & 26 & 130 & 105,22 & 16,82 \\
\hline
\end{tabular}

Table 2. Some basic descriptive parameters and results of one-way analyses of variance of the model variables according to the adolescents' gender $\left(\mathrm{N}_{\mathrm{m}}=378 ; \mathrm{N}_{\mathrm{f}}=520 ; \mathrm{df}=1 / 896\right)$.

\begin{tabular}{|c|c|c|c|c|c|c|}
\hline \multirow{2}{*}{ Dependent variable } & \multicolumn{2}{|c|}{ Mean } & \multicolumn{2}{|c|}{ SD } & \multirow[b]{2}{*}{$\mathrm{F}$} & \multirow[b]{2}{*}{$p$} \\
\hline & Male & Female & Male & Female & & \\
\hline RFP & 4.20 & 4.16 & 0.889 & 0.899 & 0.45 & 0.501 \\
\hline RMP & 4.43 & 4.45 & 0.812 & 0.756 & 0.14 & 0.705 \\
\hline PSM & 45.12 & 41.44 & 14.61 & 15.17 & 13.29 & 0.000 \\
\hline PSF & 46.25 & 44.63 & 15.04 & 16.26 & 2.32 & 0.128 \\
\hline SL & 21.81 & 18.72 & 7.968 & 7.152 & 36.95 & 0.000 \\
\hline $\mathrm{FQ}$ & 97.03 & 111.17 & 17.76 & 13.25 & 186.7 & 0.00 \\
\hline
\end{tabular}

Table 3. Correlations between the model variables on the entire sample of adolescents ( $N=898$ ).

\begin{tabular}{cccccc} 
& RFP & RMP & PSM & PSF & SL \\
\hline RMP & 0.479 & - & & & \\
\hline PSM & -0.224 & -0.284 & - & & \\
\hline PSF & -0.317 & -0.231 & 0.705 & - & - \\
\hline SL & -0.172 & -0.147 & 0.448 & 0.420 & -0.558 \\
\hline FQ & 0.148 & 0.158 & -0.289 & -0.238 & \\
\hline
\end{tabular}

Note: All correlations significant at $p<.001$ 
Table 4. Correlations between the model variables for specific groups of adolescents according to their gender, with the correlations on the male group $\left(\mathrm{N}_{\mathrm{m}}=378\right)$ above the diagonal, and the correlations for the female group $\left(\mathrm{N}_{\mathrm{f}}=520\right)$ below it.

\begin{tabular}{lllllll}
\hline & RFP & RMP & PSM & PSF & SL & FQ \\
\hline RFP & 1 & 0.505 & -0.272 & -0.346 & -0.213 & 0.204 \\
\hline RMP & 0.461 & 1 & -0.296 & -0.252 & -0.167 & 0.158 \\
\hline PSM & -0.197 & -0.276 & 1 & 0.800 & 0.402 & -0.304 \\
\hline PSF & -0.301 & -0.217 & 0.800 & 1 & 0.354 & -0.239 \\
\hline SL & -0.154 & -0.131 & 0.482 & 0.510 & 1 & -0.546 \\
\hline FQ & 0.148 & 0.181 & -0.229 & -0.248 & -0.526 & 1 \\
\hline
\end{tabular}

Note: All correlations significant at $p<.001$

To test for significant differences in the levels of the model variables according to gender, one-way analyses of variance were conducted (Table 2). There were significant differences in the assessed parental styles of mothers, social loneliness, and friendship quality. Specifically, the male adolescents assessed a more negative maternal parental style, a higher level of social loneliness, and lower friendship quality than the female adolescents did.

The hypothesized model was estimated by conducting path analysis using the program Mplus 6.12 (MUTHEN \& MUTHEN) and Estimator ML (Maximum Likelihood). The model was first tested on the whole sample to see how it functions in general, which was then followed by multigroup analysis to see if it is viable when conducted on gender subsamples and to test the assumptions of gender differences in the model relations. The model was overidentified with 5 $d f$. Along with computing the Chi-square value and its significance, goodness of fit was evaluated using the standardized root mean square residual (SRMR), root mean square of approximation (RMSEA), comparative fit index (CFI) and Tucker-Lewis Index (TLI). Guided by suggestions provided in Hu and Bentler (1999), acceptable model fit was defined by the following criteria: RMSEA $\leq .06$; SRMR $\leq .08 ; \mathrm{CFI} \geq .95 ; \mathrm{TLI} \geq .95$. Multiple indices were used because they provide different information about model fit (i.e., absolute fit, fit adjusting for model parsimony, fit relative to a null model). In the estimation of the primarily hypothesized model, the indices of overall goodness of fit were not satisfactory. Inspection of standardized residuals (greater than the 2.58 value criteria suggested by Byrne, 1998) and modification indices (greater than 10) suggested replacing the correlation between the mother's and the father's parental style with a direct path, which seemed theoretically even more acceptable than a mere correlational relationship. After including both paths (from mother's to father's parental style and vice versa) there were no more modification indices greater than 10 , and the fit indices, which are shown in Table 5, suggested that the model fitted the data well. A display of this model, including the path coefficients and correlation between the output dependent variables (social loneliness and friendship quality), is shown in Figure 3. All the path coefficients are significant except for the path from father's parental style and the adolescents' friendship quality. The estimates and significance tests of the sum of indirect effects, which show whether the hypothesized mediations are significant, are shown in Table 6 . The residual variances of the dependent variables are shown in Table 7. It is evident that all the sums of the hypothesized indirect effects are significant at the $p<.05$ level when tested on the total sample, and that there is still a relatively high level of variance which was not explained successfully with the model variables and relations (Table 7).

Table 5. Fit indices for the modified hypothesized model on the entire sample and on multiple groups according to gender.

\begin{tabular}{cccccccc}
\hline Model & $\chi^{2}$ & $\mathrm{df}$ & $\mathrm{p}$ & SRMR & RMSEA & $\mathrm{CFI}$ & $\mathrm{TLI}$ \\
\hline Whole sample & 9.429 & 5 & 0.093 & 0.022 & 0.031 & 0.997 & 0.991 \\
\hline $\begin{array}{c}\text { Multigroup } \\
\text { Male/Female }\end{array}$ & $\begin{array}{c}15.446 \\
7.504 / 7.942\end{array}$ & 10 & 0.1166 & 0.028 & 0.035 & 0.996 & 0.988 \\
\hline
\end{tabular}

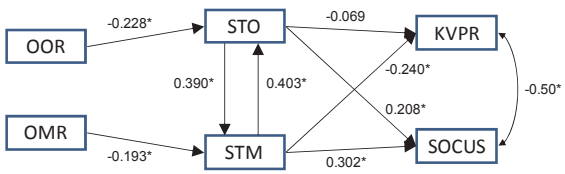

Figure 3. A display of the modified hypothesized model estimated on the entire sample of adolescents $(\mathrm{N}=898)$ with standardized path coefficients (STDYX²) and the correlation between the dependent variables. ${ }^{*}<<.001$

2 STDYX standardization uses the variances of the continuous latent variables as well as the variances of the background and outcome variables. 
The multigroup path analysis was conducted by testing the modified hypothesized model from the previous analysis conducted on the entire sample. The parameters were estimated freely (i.e., there were no equality constraints across or within groups). Goodness of fit indices, shown in Table 5, suggest that the model fits the data well on both male and female adolescent subsamples (Table 5), although there were a few interesting differences in the significance of path coefficients and of the indirect effects (shown in Figures 4 and 5 and Table 6 ). As was already shown while estimating the model on the entire sample, the path from father's parental style to friendship quality is nonsignificant, but only for the female subsample, while it is significant ( $p=.029)$ for the male subsample. The significance of this 'difference', along with the significance of all the other path coefficient differences, was tested by constraining the path coefficient of interest to be equal among groups $(d f=11)$ and conducting a chi-square difference test $(\Delta d f=1)$. Therefore, eight chi-square difference tests were conducted. In this case, constraining the path from father's parental style to friendship quality to be equal for boys and girls resulted in a 17.461 chi-square value. The chi-square difference value is $\Delta x^{2}=2.015$ (17.46115.446), which is below the critical value of the chi-square distribution at $d f=1\left(x^{2}=3.841\right)$, indicating that these path coefficients are actually not significantly different across groups at the $p<.05$ level $(p=.156)$. The only path that was shown to vary significantly between the male and female adolescent groups was the path from the father's parental style (PSF) to social loneliness (SL) $\left(\Delta x^{2}=2.015 ; p=.013\right)$. The path coefficient from father's parental style to social loneliness is higher on the male sample $(0.346)$ than on the female sample (0.163). All the sums of indirect effects (mediations) included in the model are significant at the $p<.05$ level, except for the sum of indirect effects from father's relationship with parents and friendship quality through father's parental style when it comes to male adolescents $(p=.06$; Table 6$)$. Therefore, father's parental style was not a statistically significant mediator in the relationship between the father's relationship with his parents and the friendship quality of his son. There are also some interesting differences in the residual variances shown in Table 7. Specifically, there is relatively less unexplained variance of the parental styles of both parents by the model tested on the assesments of male adolescents in comparison to female adolescents, and somewhat lower unexplained variance of social loneliness by the model tested on male-adolescent assessments.

We were also interested in the differences between path coefficients within each group, which would show if there are differential effects according to parent gender and according to the social adjustment indicator (social loneliness and friendship quality). Using the same method of testing for significant differences $(\Delta d f=1)$, we found that the father's parental style has a greater influence on the social loneliness than on the friendship quality of male adolescents $\left(\Delta x^{2}=\right.$ 10.408; $p=.001)$. The same was found for the female adolescents $\left(\Delta x^{2}=5.01 ; p=.025\right)$. Other path coefficients did not differ significantly in the male adolescent sample, while there were two more significant differences in the female adolescent sample. Namely, there was a significant difference between the path coefficients from the mother's parental style to the two measured indicators of social adjustment $\left(\Delta x^{2}=32.684 ; p=.000\right)$. This could be due to the fact that a mother's parental style of lower acceptance, higher rejection, and higher psychological control has a negative influence, being associated with a lower level of friendship quality (path coefficient with a negative sign) and higher level of social loneliness (path coefficient with a positive sign). The effect of parental style on friendship quality of female adolescents differed significantly according to parent gender $\left(\Delta x^{2}=3.874 ; p=.049\right)$. The mother's parental style had a higher influence on friendship quality than the father's parental style did.

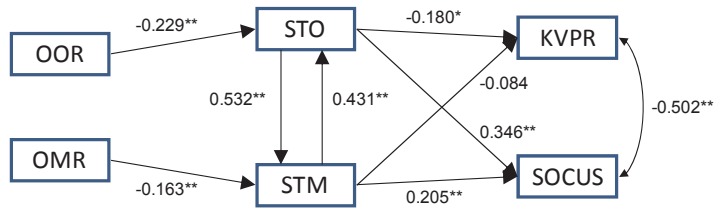

Figure 4. A display of the modified hypothesized model estimated on the sample of male adolescents $(\mathrm{N}=378)$ with standardized path coefficients (STDYX) and the correlation between the dependent variables. ${ }^{*} p<.05$; ${ }^{* *} p<.005$

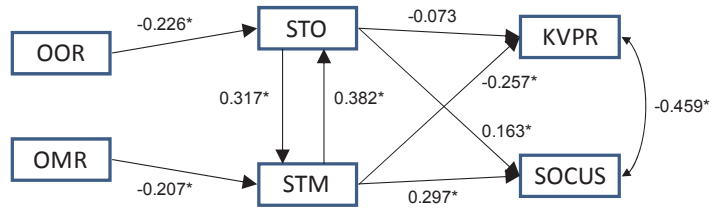

Figure 5. A display of the modified hypothesized model estimated on the sample of female adolescents $(N=520)$ with standardized path coefficients (STDYX) and the correlation between the dependent variables. ${ }^{*} p<0.008$ 
Table 6. Sum of indirect effects hypothesized in the modified model tested on the entire sample and on multiple groups by gender (STDYX standardization).

\begin{tabular}{llcccc}
\hline Subsample & Effects & Estimate & S.E. & Est./S.E. & Two-tailed p-value \\
\hline \multirow{4}{*}{ Whole sample } & From RFP to SL via PSF & -0.104 & 0.023 & -4.629 & 0.000 \\
\cline { 2 - 5 } & From RMP to SL via PSM & -0.105 & 0.021 & -4.881 & 0.000 \\
\cline { 2 - 5 } & From RFP to FQ via PSF & 0.073 & 0.016 & 4.662 & 0.000 \\
\cline { 2 - 5 } Male adolescents & From RMP to FQ via PSM & 0.052 & 0.016 & 3.165 & 0.002 \\
\cline { 2 - 5 } & From RFP to SL via PSF & -0.175 & 0.040 & -4.381 & 0.000 \\
\cline { 2 - 5 } & From RMP to SL via PSM & -0.097 & 0.039 & -2.470 & 0.014 \\
\cline { 2 - 5 } & From RFP to FQ via PSF & 0.044 & 0.024 & 1.881 & 0.060 \\
\cline { 2 - 5 } Female adolescents & From RMP to FQ via PSM & 0.087 & 0.027 & 3.201 & 0.001 \\
\cline { 2 - 5 } & From RFP to SL via PSF & -0.075 & 0.026 & -2.934 & 0.003 \\
\cline { 2 - 5 } & From RMP to SL via PSM & -0.096 & 0.024 & -3.960 & 0.000 \\
\cline { 2 - 5 } & From RFP to FQ via PSF & 0.076 & 0.020 & 3.837 & 0.000 \\
\cline { 2 - 5 } & From RMP to FQ via PSM & 0.045 & 0.021 & 2.192 & 0.028 \\
\hline
\end{tabular}

Table 7. Residual variances of the dependent variables from the model tested on the entire sample and multiple groups by gender (STDYX standardization).

\begin{tabular}{lccccc}
\hline Subsample & Variable & Estimate & S.E. & Est./S.E. & Two-tailed p-value \\
\hline \multirow{4}{*}{ Whole sample } & SL & 0.778 & 0.024 & 31.846 & 0.000 \\
\cline { 2 - 5 } & FQ & 0.914 & 0.018 & 51.295 & 0.000 \\
\cline { 2 - 5 } & PSF & 0.565 & 0.050 & 11.213 & 0.000 \\
\cline { 2 - 5 } Male adolescents & PSM & 0.543 & 0.046 & 11.804 & 0.000 \\
\cline { 2 - 5 } & SL & 0.725 & 0.039 & 18.572 & 0.000 \\
\cline { 2 - 5 } & FQ & 0.936 & 0.024 & 38.552 & 0.000 \\
\cline { 2 - 5 } & PSF & 0.406 & 0.057 & 7.145 & 0.000 \\
\hline \multirow{3}{*}{ Female adolescents } & PSM & 0.444 & 0.078 & 5.723 & 0.000 \\
\cline { 2 - 5 } & SL & 0.823 & 0.030 & 27.146 & 0.000 \\
\cline { 2 - 5 } & FQ & 0.904 & 0.025 & 36.914 & 0.000 \\
\cline { 2 - 5 } & PSF & 0.650 & 0.074 & 8.826 & 0.000 \\
\cline { 2 - 5 } & PSM & 0.603 & 0.056 & 10.692 & 0.000 \\
\hline
\end{tabular}

\section{Discussion}

One of the aims of this study was to determine whether there is intergenerational transmission of the quality of the relationship between parents and children. For this reason, adolescents evaluated the relationship between their parents and grandparents and their own relationship with their parents. In this way, estimates on two levels of parent-child relationships were obtained: the G2-G1 relationship and the G2-G3 relationship. In this research, the indirect effects of parenting on social-adjustment variables were obtained. These variables were measures of two aspects of adolescents' close relationships: adolescent-best friend relationship quality and social loneliness in the peer context.

Based on the results, we tried to determine whether we can generally speak about parent-child relationship quality transmission and to test the validity of a direct model of intergenerational transmission similar to the model proposed by Van ljzendoorn (1992). We were also interested in the possible specificity of parenting transmission according to parent and adolescent gender and in the effects of this transmission on adolescents' close relationships.

The results of this study confirm the hypothesis of the intergenerational transmission of parenting. Specifically, it is obvious that there is a significant association between the adolescents' parents and grandparents (G2-G1) and between the parents and adolescents (G2-G3). In other words, parents who have (or had) a relationship of higher quality with their own parents achieve a relationship of higher quality with their children. The current parental role is similar to the experience that parents have (or had) with their parents (Chen \& Kaplan, 2001; Putallaz et al., 1998).

Looking at the results obtained on the entire sample, i.e. girls and boys together, the father's parenting style is not associated with the adolescents' friendship quality (with a best friend), as opposed to social loneliness, which is significantly associated with both the mother's and father's parenting style. Friendship quality is a dimension of peer relationships involving trust and entrusting. Therefore, it is not surprising that fathers, who are generally less involved in 
sharing sensitive topics with their adolescent children (Bukatko \& Daehler, 2001; Colin, 1996; Han \& Jun, 2013), have a minor role in the prediction of behaviour associated with social relationships. On the other hand, while considering the resulting model, it can be concluded that the mother's parenting style is a more powerful predictor of the quality of the social relationships her adolescent child achieves by interacting with peers. These results confirm the results of many studies which suggest a significant role of parenting quality in the adjustment of children and adolescents (Maccoby, 2008; Buist et al., 2004; Choo, 2000), especially of the mother (Hoffman, Ushipz, \& Levy-Shiff, 1988; Choo, 2000; Colin, 1996). Generally speaking, the results of this research confirm a greater contribution of the mother's parental style on friendship quality and social loneliness among adolescents. The results are in accordance with parental-investment theory, which proposes that gender differences in parental investment are related to long-term and short-term mating strategies (Geher et al., 2007).

It is also important to note that the parental styles of both parents are significantly associated with each other or harmonized. The harmonization of the parenting styles of the mother and the father is likely to increase in adolescence due to the efficiency in daily functioning with the adolescent at home. It is important to emphasize that, despite the fact that the roles of the mother and father are different and contribute differently to the child's development, their partnership, which reflects on parenting, plays an important role in social development. Finally it should be noted that the results of this study support the direct model of intergenerational transmission of parenting, and that parenting style (transmitted) plays an important role in the social competence of adolescents, measured by the quality of dyadic relationships with their best friend and with the feeling of loneliness in the peer context.

The next question we tried to answer relates to the specificity of the interaction between mothers and fathers in relation to the adolescents' genders. The results of our study suggest conclusions like those of many earlier studies which showed that the role of the mother is mostly protective and caring, and the role of the father is instrumental (Deković \& Raboteg-Saric, 1997, Bukatko \& Daehler, 2001; Colin, 1996). Specifically, the father's parental style is predictive of the friendship quality and social loneliness of his son. This role is stronger for social loneliness. It seems that the topics of friendship and close peer relationships are not, however, common to fathers and sons. Sons probably do not even talk to their mother about these issues, since the predictive value of the mother's parental style is insignificant. These results are not surprising when considering the way young men pursue friendships. Their friendships are not saturated with intimate, confidential information; they are based more on common, joint activities and mutual instrumental help (Buhrmester, 1996). Therefore, it is rather unlikely that young men share such topics with their fathers, and especially with their mothers. On the other hand, feelings of social loneliness can be predicted on the basis of the parental style of both the father and the mother, but the father's role is greater. A father's role as an 'extended arm' of society seems to have a significant role in the settling of a young man in a wider social, peer context (Deković \& Raboteg-Šaric, 1997). The father's role is to encourage the social activities of his son, as indicated by the results obtained. We conclude that a positive parenting style on the part of the father is associated with the son's friendship quality, and, along with a positive parenting style in the mother, contributes to less social loneliness.

Observation of the female adolescents shows a relatively weaker role of the father in relation to the role of the mother. Research results confirm that girls confide more to their mothers, especially on topics that are confidential, including friendships, and so they have more opportunities to influence their daughter's behaviour (Updegraff, McHale, Grouter, \& Kupanoff, 2001). The father's role in this aspect of his daughter's life is not very significant. As for the other measured dimension of peer interaction, social loneliness, both the mother and the father have a significant role among girls, but the mother's role is greater. Indirectly, the results obtained confirm the different meanings that male and female adolescents attribute to peer interactions. A friendship that involves sharing, entrusting, and intimacy is important to girls, while socializing and spending time in a joint activity is important to boys (Way, 2006; Buhrmester, 1996).

\section{Conclusions}

Despite the shortcomings of this study, we can conclude that we have confirmed the intergenerational transmission of parenting from the generation of grandparents (G1) through the generation of parents (G2) to the generation of adolescents (G3). Parents who have (or had) a more positive relationship with their parents have a more positive parenting style (more acceptance, less rejection, and less psychological control) towards their adolescent child.

Generally, the results of this research show a greater impact of the mother's parental style on friendship quality and social loneliness for girls than for boys. Also, the father's parental style has a greater impact on the output variables of male adolescents, especially the feeling of loneliness. The father's parental style has a minimal effect for the female adolescents. The results emphasize the necessity of distinguishing the roles of mothers and fathers separately for girls and boys. 
When analysing the relationships between the parental style of the father and the mother regarding the adolescents' gender, it can be noticed that there is a greater influence of the father's parental style on social loneliness for the group of male adolescents than for female adolescents. There were no differences in the strengths of other relationships in the hypothetical model according to adolescent gender. Therefore, the mother and father manifest a similar parental style towards their sons and daughters.

The results of this research show that there is a stronger direct effect of the mother's parental style on the female adolescents' friendship quality, in comparison to the father's parental style, and suggest the importance of distinguishing between the parental styles of fathers and mothers and their impact on the social development of their male and female children.

The limitations of this study relate to the data which is collected retrospectively; therefore, there is the possibility of forgetting or redefining parenting by G2. Furthermore, the assessments collected were given by adolescents, who may not have an objective enough insight into the relationships of their parents with their grandparents. But this could also be an advantage of this research, given that the assessors at all levels $(G 2, G 3)$ are the same. Also, the perspective from which the adolescents evaluate level G3 is extremely relevant to their assessment of all dependent variables at level G2 (and perhaps even more relevant than a possible direct assessment of the G3 level on the part of their parents).

It is also important to emphasize that the relationship between parents and their parents (G1 - G2) was measured by a general assessment of the quality of their relationship, while the relationship between adolescents and parents was measured on three dimensions of parenting, and thus was operationalized much more concretely. Future research should focus on uniform measures of assessment.

\section{References}

Amato, P.R. (1996). Explaining the transgenerational transmission of divorce. Journal of Marriage and Family, 58, 628-640.

Amato, P.R., Cheadle, J. (2005). The long reach of divorce: Divorce and child well-being across three generations. Journal of Marriage and Family. 67(1), 191-206.

Bailey, J.A., Hill, K.G., Oesterle, S., Hawkins, D. (2009). Parental practices and problem behavior across three generations: Monitoring, harsh discipline, and drug use in the intergenerational transmission of externalizing behavior, Developmental Psychology, 45 (5), 1214-1226.

Bjorklund, D.F., Shackelford, T.K. (1999). Differences in Parental Investment Contribute to Important Differences Between Men and Women. Current Directions in Psychological Science, 8 (3), 86-89.

Bowlby, J. (1973). Attachment and loss: Vol. 2. Separation, Anxiety and Anger. New York: Basic Books.

Buhrmester, D. (1996). Need fulfillment, interpersonal competence, and the developmental contexts of early adolescent friendship. In: W.M. Bukowski, A.F. Newcomb \& W.W. Hartup (Eds.). The company they keep - friendship in childhood and adolescence (pp.158-186). United Kingdom: Cambridge University Press.

Buist, K.L., Deković, M., Meeus, W.H., \& van Aken, M.A.G. (2004). Attachment in Adolescence: A Social Relations Model Analysis. Journal of Adolescent Research, 19 (6), 826-850.

Bukatko, D., Daehler, M.W. (2001). Child Development - a thematic approach. New York: Houghton Mifflin Company.

Buss, D.M. (2005). The Handbook of Evolutionary Psychology. New Jersey: John Waley \& Sons, Inc.

Byrne, B. (1998). Structural Equation Modeling with LISREL, PRELIS, and SIMPLIS: Basic applications and programs. New Jersey: Lawrence Erlbaum.

Campbell, J., Gilmore, L. (2007). Intergenerational continuities and discontinuities in parenting styles, Australian Journal of Psychology, $59(3), 140-150$.

Castellana, M., Vilar, I., \& Rodriguez-Tome, H. (1997). Who are VIPs for adolescents? Persones significatives en el mon dels adolescents. Poster session presented at the VII European Conference on Development Psychology. Rennes.

Chen, Z., Kaplan, H.B. (2001). Intergenerational Transmission of Constructive Parenting, Journal of Marriage and Family, 63, 17-31. DOI: $10.1111 /$ /.1741-3737.2001.00017.x

Choo, O.A. (2000). Parenting Behaviours and Adolescents' Psychosocial Adjustment, Gender Differences and Ethnicity Issues in Parenting in an Asian Context. Retrieved from http://www.aare.edu.au/00pap/ong00466.htm.

Colin, V.L. (1996). Human attachment. New York: The McGraw-Hill Companies, Inc.

Collins, N., \& Read, S.J. (1994). Cognitive representations of attachment: The structure and function of working models. In D. Perlman \& K. Bartholomew (Eds.), Advances in personal relationships (Vol. 5, pp. 53-90). London: Jessica Kingsley.

Crittenden, P. M. (2008). Raising parents: Attachment, parenting, and child safety. Abingdon, UK: Routledge/Willan.

Crittenden, P. M. (1984). Sibling interaction: Evidence of a generational effect in maltreating families. International Journal of Child Abuse and Neglect, 8, 433-438.

Ćubela-Adorić V, Nekić M. (2004). Skala Socijalne i emocionalne usamljenosti [The scale of social and emotional loneliness]. In: A. Proroković, K. Lacković-Grgin, V. Ćubela-Adorić, Z. Penezić (Eds). Zbirka Psihologijskih Skala i Upitnika. Svezak 2. [Collection of Scales and Psychological Questionnaires. Volume 2] (pp. 52-61). Zadar: Sveučilište u Zadru. Croatian.

Deković, M., \& Buist, K.L. (2005). Multiple Perspectives within the Family. Journal of Family Issues, 26 (4), 467-490. 
Deković, M. i Raboteg-Šarić, Z. (1997). Parental Child Rearing Practices and Adolescent Peer Relations, Društvena istraživanja, 6 (4-5), 427-445.

Dronkers, J., \& Härkönen, J. (2008). The intergenerational transmission of divorce in cross-national perspective: Results from the Fertility and Family Surveys, Population Studies. A Journal of Demography, 62 (3), 273-288.

Eichelsheim, V.I., Deković, M., \& Buist, K.L. (2009). The Social Relations Model in Family Studies: A Systematic Review. Journal of Marriage and Family, 71, 1052-1069.

Feeney, J.A., Noller, P., \& Roberts, N. (2000). Attachment and close relationships. In C. Hendrick, \& S.S. Hendrick (Eds.), Close Relationships (pp. 185-203). London: Sage Publications, Inc.

Feldman, P.H., \& Goldsmith, L.T. (1986). Intergenerational influences on the development of early prodigious behavior: A case study approach. New Directions for Child Development, 32, 67-85.

Fry, D.P. (1993). The intergenerational transmission of disciplinary practices to conflict. Human Organization, 52 (2), pp.176-185.

Geary, D. C. (2005). Evolution of paternal investment. In D. M. Buss (Ed.), The evolutionary psychology handbook (pp. 483-505). Hoboken, NJ: John Wiley \& Sons.

Geher, G., Fairweather, K., Mollette, N., Ugonabo, U., Murphy, J.W. \& Wood, N. (2007). Sex Differences in Response to Cues of Parental Investment: An Evolutionary Social Psychological Perspective. Journal of Social, Evolutionary and Cultural Psychology, 1 (2), 18-34.

Goodnow, J.J. (1995). Parents' knowledge and expectations. In M.H. Bornstein (Ed.), Handbook of parenting: Status and social conditions of parenting (Vol. 3, pp. 305-332). Mahwah: NJ: Erlbaum.

Han, Y.S., Jun, W.P. (2013). Parental Involvement in Child's Development: Father vs. Mother. Open Journal of Medical Psychology, 2 , $1-6$

Herman, J.L. (1995). Intergenerational transmission of parenting and adolescent problem behaviors, A Dissertation Presented to the Graduate Faculty of the University of Virginia.

Hoffman, M.A., Ushpiz, V., \& Levy-Shiff, R. (1988). Social Support and Self-esteem in Adolescence. Journal of Youth and Adolescence, 17, 4, 307-316.

Hu, L. \& Bentler, P.M. (1999). Cutoff criteria for fit indexes in covariance structure analysis: Conventional criteria versus new alternatives. Structural Equation Modeling, 6, 1-55.

Klarin M. (2000). Odnosi u Obitelji is Vršnjacima kao Prediktori Razlićitih Aspekata Prilagodbe u Školi [Relations in the Family and with Peers as Predictors of Different Aspects of Adjustment in School] [doctoral dissertation]. Filozofski fakultet u Zagrebu. Croatian.

Klarin, M., Šimić Šašić, S., \& Proroković, A. (2012). The Contribution of Family and Peer Interaction to the Understanding of Self-Esteem in Adolescents - Gender and Cultural Similarities and Differences. International Journal of Humanities and Social Science, 2 (21), 1-12.

Kline, R. B. (2011). Principles and Practice of Structural Equation Modeling, Third Edition. New York: The Guilford Press.

Kunz, J. (2000). The intergenerational transmission of divorce: A nine generation study. Journal of Divorce and Remarriage, 34, 196175.

Maccoby, E. (2008). Overview of Socialization Research and Theory, In J.E. Crusenc \& P.D. Hastings (Eds.), Handbook of Socialization - Theory and Research (pp. 13-42). New York: The Guilford Press.

Macuka, I. (2007). Skala percepcije roditeljskog ponašanja - procjena valjanosti (Perceptions of parental behavior Scale - Validity Assessment). Suvremena psihologija, 10 (2), 179-199. Croatian.

Pears, K.C., Capaldi, D.M. (2001). Intergenerational transmission of abuse: a two-generational prospective study of an at-risk sample. Child Abuse \& Neglect, 25 1439-1461.

Putallaz, M., Costanzo, P.R., Grimes, S.L., \& Sherman, D.M. (1998). Intergenerational Continuities and Their Influences on Children's Social Development. Social Development, 7 (3), 389-427.

Rogoff, B. (2003). The Cultural Nature of Human Development, Oxford: Oxford University Press.

Roskam, I. (2013). The transmission of parenting behaviour within the family: an empirical study across three generations, Psychologica Belgica, 53, 3, 49-64.

Rutter, M., Quinton, D. \& Hill, J. (1990). Adult outcome of institution-reared children: Males and females compared. In L.N. Robins \& M. Rutter (Eds.), Straight and deviant pathways from childhood to adulthood (pp. 135-157). New York: Cambridge University Press.

Serbin, L.A., \& Karp, J. (2004). The Intergenerational Transfer of Psychosocial Risk: Mediators of Vulnerability and Resilience. Annual Review of Psychology, 55, 333-363.

Serbin, L.A., \& Karp, J. (2003). Intergenerational Studies of Parenting and Transfer of Risk From Parent to Child. Current Directions in Psychological Science, 12 (4), 138-142.

Serbin, L.A., Cooperman, J.M., Peters, P.L., Lehoux, P.M., Stack, D.M., \& Schwartzman, A.E. (1998). Intergenerational transfer of psychosocial risk in women with childhood histories of aggression, withdrawal, or aggression and withdrawal. Developmental Psychology, 34 (6), 1246-1262.

Shaffer, A., Burt, K.B., Obradović, J., Herbers, J.E., \& Masten, A.S. (2009). Intergenerational Continuity in Parenting Quality: The Mediating Role of Social Competence. Developmental Psychology, 45 (5), 1227-1240.

Sharma, N., \& Vaid, S. (2005). Role of Parents in the Social Development of Adolescents: A Comparison of Low and Middle SocioEconomic Status. J.Hum. Ecol., 18 (2), 109-115.

Simons, R., Whitbeck, L., Conger, R. \& Chyi-In, W. (1991). Intergenerational transmission of harsh parenting. Developmental Psychology, 27 (1), $159-171$ 
Tabachnick, B. \& Fidell, L. S. (2001). Using Multivariate Analysis (4th edition). Boston: Allyn and Bacon.

Tanaka, M., Kitamura,T.,Chen,Z., Murakami,M \& Goto,Y. (2009). Do parents Rear their Children as they were Reared Themselves? Intergenerational Transmission of Parental Styles (Warmth and Control) and Possible Mediation by Personality Traits. The Open Family Studies Journal, 2, 82-90.

Updegraff, K., McHale, S., Grouter, A., \& Kupanoff, K. (2001). Parents' involvement in adolescents' peer relationships: A comparison of mothers' and fathers' roles. Journal of Marriage and Family, 63, 644-658.

Van ljzendoorn, M, H. (1995). Adult attachment representations, parental responsiveness and infant attachment: A meta-analysis on the predictive validity of the adult attachment interview. Psychological Bulletin, 117, 387-403.

Van ljzendoorn, M, H. (1992). Intergenerational Transmission of Parenting: A Review of Studies in Nonclinical Populations. Developmental Review, 12 (1), 76-99.

Way, N. (2006). The Cultural Practice of Close Friendships Among Urban Adolescents in the United States. In: X. Chen, D.C. French \& B.H. Schneider (Eds.), Peer Relationships in Cultural Context (pp. 406-426). New York: Cambridge University Press.

Youniss, J., Smollar, J. (1985). Adolescent relationships with mothers, fathers, and friends. Chicago: University of Chicago Press. 